\title{
САТИРИЧНА ГРАФІКА ХУДОЖНИКІВ ПРЕСОВОЇ КВАРТИРИ УСС О. КУРИЛАСА ТА О. СОРОХТЕЯ
}

\begin{abstract}
У статті опращьовано наукові дослідження, які висвітлюють творчість художників-графіків стрільців у сатиричних часописах Пресової квартири Украӥнських Січових Стрільиів (УСС).

Зазначено, що Пресова квартира УСС стала осередком творчості для талановитих стрільців-художників, щчо працювали над різноманітними друкованими проектами січовиків, серед яких особливе місие займає сатирична преса. Ці видання були створені в польових умовах і мали велике значення для підняття бойового духу та позитивного настрою в легіоні стрільйів. Завдяки художникам Пресової квартири сатиричні часописи УСС, щุо наповнювалися майстерними карикатурами та шаржами, мають не тільки історичну, але й високу художню циінність. Творчість ілюстраторів у гумористично-сатиричній літературі легіону січових стрільців мала подальший вплив на розвиток украӥнської друкованої графіки.

У статті досліджено творчість художників-карикатуристів О. Куриласа, О. Сорохтея в період їхньої роботи у пресових виданнях УСС. Проведено мистецтвознавчий аналіз карикатур та шаржів відповідних художників-січовиків, щз допоміг порівняти, описати, розібрати графічні твори. Розглянуто особливості творчої манери митців, зміст карикатур, художні та технічні засоби виконання. 3'ясовано, щчо графіка О. Куриласа відрізняється динамізмом та алегоризмом, виразністю в передачі характерів персонажів, тоді як О. Сорохтей тяжіє у своїх творах до статики, опрацьовує образи точним контуром, наділяє портрети психологізмом та гострою сатирою. Наголошено, щу зазначені митиі мають спільні творчі риси - у своїх сатиричних творах використовують гротескність, експресію форми та лінї в передачі характерів персонажів. О. Курилас та О. Сорохтей мають західну художню освіту, що передбачає володіння високим рівнем академічного рисунку.

Підкреслено, щз творчість художників-січовиків не обмежувалася лише пропагандою. У творах карикатуристів стрілецьких часописів простежується критика військового командування УСС, висміювання помилок $i$ недоліків стрільиів, демонструються шаржі на відомих у стрілецькому середовищі осіб.
\end{abstract}

Ключові слова: карикатура, шарж, художник-стрілець, художник-січовик, сатиричне видання, Пресова квартира УСС.

Viktor MYKHALEVYCH, orcid.org/0000-0003-4847-5833 Candidate of Cultural Studies, Associate Professor, Associate Professor at the Department of Fine Arts Borys Grinchenko Kyiv University (Kyiv,Ukraine)v.mykhalevych@kubg.edu.ua

\section{SATIRICAL GRAPHICS OF THE ARTISTS OF THE USR PRESS APARTMENT O. KURYLAS AND O. SOROKHTEI}

The article deals with scientific research that covers the work of Riflemen graphic artists in satirical magazines of the Ukrainian Sich Riflemen (USR) Press Apartment.

It is noted that the Press Apartment of the USR has become a center of creativity for talented Riflemen artists who worked on various printed projects of the Sich, among which a special place refers to the satirical press. These publications were created in the field and were of great importance for raising morale and positive mood in the Legion of Riflemen. Thanks to the artist of the Press Apartment, USR satirical magazines, filled with masterful caricatures and cartoons, have not only historical but also high artistic value. The work of illustrators in the humorous and satirical literature of the Sich Riflemen's Legion had a further influence on the development of Ukrainian printed graphics.

The article examines the work of cartoonists O. Kurylas, O. Sorokhtei during their work in the press publications of the USR. An art analysis of caricatures and cartoons of relevant Sich artists was conducted, which helped to compare, describe and analyze graphic works. Peculiarities of artists' creative style, content of caricatures, artistic and technical means of execution are considered. It was found that the graphics of $O$. Kurylas are dynamic and allegorical, expressive 
in the transfer of characters, while O. Sorokhtei tends to statics in his works, processes images with a precise contour, gives portraits psychologism and sharp satire. It is emphasized that these artists have common creative features - in their satirical works use grotesqueness, expression of form and line in the transfer of characters. O. Kurylas and O. Sorokhtei have a western art education, which requires a high level of academic drawing.

It was emphasized that the work of Sich artist was not limited to propaganda. In the works of cartoonists of Riflemen's magazines there is a critique of the USR military command, ridicule of mistakes and shortcomings of Riflemen artists, cartoons on well-known people in the riflemen environment are shown.

Key words: caricature, cartoon, Rifleman artist, Sich artist, artist satirical edition, USR Press Apartment.

Постановка проблеми. Пресова квартира Українських Січових Стрільців (далі - УСС) стала унікальним явищем в українській культурі. Серед літератури, яку видавали в Пресовій квартирі, особливе місце займає сатирична преса, яка натепер залишається не досить дослідженою. Це був дуже важливий елемент як у військовому, так і в культурному житті стрільців. Сатиричні часописи УСС доносили не лише широкий спектр проблем загальноукраїнського та міжнародного значення, подавали іронічно-критичну оцінку тогочасним суспільно-політичним подіям Австро-Угорської імперії, а й стали наочним матеріалом у вигляді карикатур та шаржів з коментарями до щоденного життя і побуту самих стрільців. Цей візуальний матеріал виконаний художниками-стрільцями на високому професійному рівні, що є фактом в українському графічному мистецтві перших десятиліть XX ст. Тому часописи УСС мають не тільки історичну, але й художню цінність, а творчість художників-січовиків мала подальший вплив на розвиток української друкованої графіки.

Концепція мистецького та інтелектуального розвитку легіону УСС, що справляла сприятливий ефект на стан вояків-усусів, може стати в нагоді сучасному українському війську та суспільству загалом. Тому сьогодні стає актуальним дослідити творчість реалізаторів цих ідей, а саме художників-карикатуристів Пресової квартири УСС.

Аналіз досліджень. У процесі роботи над дослідженням сатиричної графіки художниківсічовиків у період їхньої творчості в Пресовій квартирі УСС були використані відповідні наукові джерела, а саме: мистецтвознавчі замітки учасників Пресової квартири М. Голубця та І. Іванця, де порівнюється художня манера О. Куриласа та О. Сорохтея; фундаментальні розвідки Д. Горняткевича, К. Рожак-Литвиненко, М. Фіголя, в яких проаналізовані стильові особливості стрілецької графіки; розвиток стрілецького образотворчого мистецтва простежений у роботах Т. Кузьменка та О. Макойди.

Треба зазначити, що в радянській період свідомо уникали тему творчості українських художників у лавах УСС. Навіть сьогодні ця проблема недостатньо висвітлена в науковій літературі.
Мета статті - висвітлити особливості сатиричної графіки художників-карикатуристів О. Куриласа та О. Сорохтея в Пресовій квартирі УСС. Проаналізувати об'єднавчі та індивідуальні риси графічної манери зазначених митців.

Виклад основного матеріалу. Події Національно-визвольної боротьби початку XX століття в Україні та Перша світова війна стали головними факторами розвитку української преси початку XX століття. Особливо це відобразилось в сатиричній періодиці галицького війська УСС.

Організований у 1914 р. окремий структурний підрозділ австрійської армії Легіон Українських січових стрільців потребував координаційного центру для національного, культурного та освітнього розвитку українських воїнів. Таким центром стала «Пресова кватира» УСС, створена у 1915 р. при Коші на Закарпатті в с. Замкова Паланка. Пресова кватира постійно змінювала свою дислокацію разом зі стрілецькими куренями. Незважаючи на це, налагоджений випуск стрілецьких видань у польових умовах відрізнявся якістю та різноманітністю. Серед них вагоме місце займали сатиричні видання, такі як «Самохотник», «Республіканський самохотник», «Бомба», «Самопал» та інші, що були насичені високохудожнім ілюстративним матеріалом. Це пояснюється тим, що при Пресовій квартирі працювали професійні художники-графіки, такі як Ю. Буцманюк, Л. Гец, І. Іванець, О. Курилас, О. Сорохтей та інші.

Відмітимо, що митці працювали в польових військових умовах. Але це тільки додало більшої виразності та правдивості їхній творчості, а також сприяло розвитку таланту молодих художників. Наведемо приклади мистецької діяльності, на нашу думку, ключових представників стрілецької сатиричної графіки - О. Куриласа та О. Сорохтея періоду роботи в журналах УСС, а також порівняємо особливості їхньої творчості.

О. Курилас, як очільник мистецького відділу Пресової кватири Легіону УСС, брав участь майже в усіх січових виданнях.

Для карикатур Куриласа характерний доброзичливий гумор, алегоричність, гротескність паралельно з точністю в передачі характерів. Графіка імпресійно легка і водночас виразно експре- 
сивна. Художник використовує широкий контур та умовну світлотінь 3 енергійною штриховкою. У своїх роботах митець застосовує динамічні композиції зі складними ракурсами, але не перевантажені деталями. Більшість портретів-шаржів та карикатур ілюстратора супроводжується відповідними підписами. 3 художніх матеріалів Курилас надає перевагу туші та перу.

Проаналізуємо особливості графічної манери художника на прикладах його карикатур у часописах УСС.

Гостротою відрізняються політичні карикатури художника. Наприклад, карикатура «Солідарність Української Парламентарної Репрезентації» демонструє боротьбу українських політиків між собою, що шкодило загальнонаціональним інтересам («Самохотник», 1917 р. Ч. 27-28). Художник показав персонажів, які тягнуть один одного та метушаться в різні боки. Наступний приклад, де зображено українськопольське братання після революції $1917 \mathrm{p}$. («Червона калина», 1917 р. Ч. 5). Тут ілюстратор висміює наївність українських політичних діячів. Багатофігурна карикатура на політичну тему «Бойова управа» відрізняється виразною мімікою та емоційними жестами персонажів («Самохотник», 1917 р. Ч. 20-21). У складних композиціях художник робить головних героїв більшими за другорядних, наприклад «Парнас у Коші» («Самохотник» 1917 р., Ч. 20-21).

Зазначимо, що багато карикатур Куриласа треба сприймати лише разом із текстом, наприклад «Розмова десятника УСС з австрійським офіцером» («Самохотник» 1917 р., Ч. 29-30, папір, туш, перо). 3 тексту ілюстрації випливає, що австрійський офіцер даремно пропонує стрільцю перейти в інші частини австрійської армії.

Динамічною є композиція карикатури, на якій зображено редактора стрілецького часопису «Червона калина» М. Угрина-Безгрішного, що стрибає через загорожі («Самохотник», 1917 р. Ч. 25-26). Художник звертає увагу на деталі, які додають кумедність ситуації, наприклад, герой, посміхаючись, тримає гроно калини в зубах, а з його волосся стирчить колючий дріт. Динамізму рисунку додає експресивна лінія та різка штриховка.

Емоційною виглядає ілюстрація, на якій стрілець прощається зі своєю коханою («Новініада», 1917 р.). Незважаючи на гротескність, художнику вдалось передати романтичні почуття героїв.

Ілюстратор використовує зооморфізм у карикатурі, наприклад, «Стрілецький шантеклє» («Самохотник», 1917 р. Ч. 34-35). У даному випадку вдалим є поєднання людини та півня.
Наведемо приклади психологічних шаржів О. Куриласа, в яких автор влучно передає характер портретованих та надає сатиричну оцінку якостям стрільців: «Чи їсти, чи пити - от питання!» («Червона калина», 1917 р. Ч. 5), «Бицьо» на Волині» («Червона калина», 1917 р. Ч. 6), «Стрілецька муза в образах» («Червона калина», 1917 р. Ч. 27-28), «УСС отрадоньки шукали» («Червона калина», 1917 р. Ч. 8), «Орудник музики УСС Михась Гайворонський» («Червона калина», 1917 р. Ч. 7), «А-a-a-a! Як ся маєте?..» («Червона калина», 1917 р. Ч. 2), «Мушу йти до війська... мушу зачинати від простого» («Червона калина», 1917 р. Ч. 5), «Тато Чумчумаха» («Самохотник», 1917 р. Ч. 27-28), «УСС мовить... « («Бомба», 1918 р. Ч. 1.) та ін. У цих прикладах для досягнення максимального виражального ефекту митець вдається до деформації образів, збільшуючи голови, змінюючи форму та розміри окремих частин обличчя, зокрема, носа та рота.

Колега Куриласа по Пресовій квартирі I. Іванець так охарактеризував сатиричну графіку художника: «Карикатури О. Куриласа мають емпіричну легкість i живописну зручність. Він маляр iз темпераментом. У його працях багато безпосередності, енергії. Художник він спостережливий, як ілюстратора його характеризує надзвичайна малярська пам'ять, як доказ - цілий ряд малюнків та портретів» (Голубець, 1936: 32).

Дослідник К. Рожак-Литвиненко зазначає: «Наскільки б серйозною не була тема чи подія, зображені О. Куриласом персонажі завжди виглядають комічними» (Рожак-Литвиненко, 2017: 153).

Перейдемо до творчості ще одного видатного карикатуриста Пресової квартири - О. Сорохтея.

Будучі в лавах УСС, Сорохтей робить характерні шаржи на побратимів та карикатури, пов'язані зі стрілецьким життям. Також сатира художника не оминала стрілецьку старшину, політичних осіб, священнослужителів. Графіка митця виділяється серед інших творів стрільцівхудожників. Персонажі в карикатурах Сорохтея виходили гостро та відверто. У сатиричних роботах ілюстратора присутній характер героїв, своєрідна стилістика, пластичність, вишуканість ліній та експресія. Художник схоплює обриси типажів точною лінією й упевнено окреслює постаті та обличчя героїв. Манера О. Сорохтея була близька до експресіонізму та модернізму з відголоском японського мінімалізму. Ілюстрації художника були технічні, хоча дещо статичні, узагальнені, м'яко трактовані, підкреслювали саркастичну злободенність. 3 матеріалів Сорохтей найчастіше користується вуглем, пером і тушшю. 
За мінімального використання технічних засобів художник передає найбільш характерне у своїх портретах шляхом гіперболізації, поєднуючи реалістичне з гротескними елементами. Це проявляється в деформації обличь і фігур персонажів. Наприклад, такі прийоми ми можемо спостерігати в серії шаржів на січових стрільців із записника художника (1917-1918рр.), на підхорунжних УСС О. Кобилянського, Черевка (бл. 1917-1918 рр.), дружній шарж на полковника УСС Г. Коссака (1916 р.), на якому зображено незграбну постать поруч із кумедною собакою.

Наступний приклад із сатиричної графіки Сорохтея - карикатура «Усусуси», що демонструє перебільшену армійську виправку, якій навчаються молоді стрільці. Особливо кумедно виглядає персонаж підхорунжого, зображений на передньому плані (Стрілецький учитель С. Прідун на вправах у Вишколі («Усусуси»). 1917 р.). Уривчасті штрихові плями в ілюстрації формують ритм та рух персонажів, що марширують.

Схожість творчості Сорохтея 3 художниками світового рівня ми можемо спостерігати в рисунку «Аркан» (1917р.), що нагадує твір А. Матісса «Танець» (1910р.). У роботі митець передає ритм, утворений стрільцями-танцівниками. Композиція створює враження, що персонажі ширяють над землею, а військова уніформа УСС підкреслює рухи танцівників. Сорохтей, як і Матісс, майстерно використовує лінію для пластичної передачі героїв. У зображенні відчувається миролюбство, свято та спокій. Схожі емоції викликає шарж «Відпочинок» (1916-1917рр.).

Колега О. Сорохтея художник-січовик І. Іванець так описав творчість свого товариша: «Художник Сорохтей - природжений карикатурист, де основна увага сконцентрована на конкретних зображеннях, він витончений митець графіки, $\epsilon$ в нього велике почуття лінії карикатури, що він виконує тушшю $\mathrm{i}$ пером, є доволі оригінальні, стають монументальними через свою якість та велике почуття форми» (Гордієнко, 1990: 32).

Січовик, видавець і мистецтвознавець М. Голубець так висловився про сатиричну графіку О. Сорохтея: «Завважую й підкреслюю, що Сорохтей не творив своїх карикатур ad usum (для вжитку) проминаючої актуальності. Він творив їх незалежно, так би сказати, від простору й часу, й тому низка його карикатур буде колись документарним матеріалом для пізнання внутрішнього обличчя цілого ряду наших сучасників» (Голубець, 1936: 5).

Сучасник Сорохтея - мистецтвознавець та художник Д. Горняткевич так охарактеризував сатиричну графіку митця: «Сорохтей імпровізу- вав у карикатурі. Мав вправну руку. Рисунок ігри ходив йому незвичайно легко, все в нього плило. А проте був страшенно вибагливий щодо техніки. Кожна його карикатура була м'яко трактована, мала в собі щось із акварелі, хоч рисована пером i тушом» (Горняткевич, 1942).

3 приводу шаржів О. Сорохтея мистецтвознавець М. Фіголь зазначає: «Тут гротеск іде в парі 3 філософським розкриттям образу, спирається на конкретизацію певних життєвих рис та ситуацій» (Фіголь, 1971: 5).

Дослідник К. Рожак-Литвиненко зазначає, що творчо найближчим українським попередником О. Сорохтея був львівський карикатурист К. Сіхульський, від якого Сорохтей запозичив лаконічну манеру зображень та експресію пародіювання $з$ присутнім трагікомізмом, що робить художника одним із перших українських графіківекспресіоністів (Рожак-Литвиненко, 2017: 154).

На нашу думку, творчість Сорохтея в період перебування у лавах УСС тяжіє як до фовізму, так і до експресіонізму. Ідейність фовізму проглядається більше, бо художник, незважаючи на військове оточення, намагався передати у своїх роботах позитивний настрій та красу.

Після розгляду особливостей творчої манери О. Куриласа та О. Сорохтея наведемо об'єднавчі риси та відмінності в сатиричній графіці художників.

Ілюстрації Куриласа та Сорохтея в стрілецьких часописах були пов'язані з текстовим матеріалом або супроводжувались текстом. Зазначені карикатуристи у своїх творах користуються прийомами гіперболізації та гротеску. На творчість художників вплинуло тогочасне західноєвропейське віяння в мистецтві - експресіонізм. Відмітимо, що О. Сорохтей та О. Курилас навчалися в європейських художніх закладах.

У сатиричних ілюстраціях О. Куриласа спостерігається доброзичливий гумор. У карикатурах та шаржах О. Сорохтея простежується гостра іронія, психологізм та сарказм. Науковець К. РожакЛитвиненко, порівнюючи творчість Куриласа та Сорохтея, зазначає: «На противагу карикатурам О. Куриласа, якого цікавили переважно веселі сторони життя стрілецтва, О. Сорохтей трактує своїх персонажів як сатирик (Рожак-Литвиненко, 2017: 155).

Для творів Куриласа характерні точність у відтворенні індивідуальних характеристик моделей та динаміка композиції. Креолізованість ілюстрацій художника має більший вплив на реципієнта завдяки підкріпленню іконічного вербальним. Сорохтей у своїй творчості надає 
перевагу мінімалізму, статичності та технічній досконалості рисунку.

Висновки. Можна підсумувати, що вищезгадані талановиті художники-карикатуристи Пресової квартири мали індивідуальну манеру виконання сатиричної графіки: роботи О. Куриласа відрізняються динамікою та виразністю характерів, творам О. Сорохтея притаманний психологізм та точність лінії. При цьому в їхній творчості про- стежуються об'єднавчі моменти, такі як західна художня освіта, експресія, гротескність.

Головною особливістю сатиричної графіки художників-січовиків у стрілецьких виданнях було те, що вона не виступала лише прямою пропагандою, а була віддзеркаленням реального щоденного життя січових стрільців, взаємостосунків між вояками, побутових конфліктів військового середовища, актуальних суспільних проблем.

\section{СПИСОК ВИКОРИСТАНИХ ДЖЕРЕЛ}

1. Голубець М. Проблеми сучасного мистецтва : (Відчит на VIII Виставі АНУМ дня 29.ІХ. ц. р.). Новий Час. 1936. № 12. C. 5-8.

2. Гордієнко В. Українські Січові Стрільці. Львів : «Львів», 1990. 134 с.

3. Горняткевич Д. Жмут споминів про Осипа Сорохтея. Zbruč. Краківські вісті. Львів. URL: https://zbruc.eu/ node/ 62915

4. Кузьменко Т. Мистецько-художня творчість українських січових стрільців у контексті розвитку національної культури першої чверті ХХ століття. Питання культурології. Київ, 2017. №. 32. С. 89-110.

5. Макойда О. Осип-Роман Сорохтей та стрілецькі часописи. Наук. зб. Спілки критиків та істориків мистецтва Ін-т народознавства НАН України. Львів, 2007. № 2. С. 45-52.

6. Рожак-Литвиненко К. Мистецьке угруповання українських січових стрільців: художники, традиції, жанрові та стильові особливості творів : дис. ... : 17.00 .05 «Образотворче мистецтво». Львів, 2017. 380 с.

7. Фіголь М. Виставка творів художника-карикатуриста Осипа Йосафатовича Сорохтея, присвячена 80-річчю з дня народження: Проспект. Івано-Франківськ : Облдрукарня, 1971. 19 с.

\section{REFERENCES}

1. Holubets M. Problemy suchasnoho mystetstva. [Problems of contemporary art]. Novyi Chas, 1936. № 12. P. 5-8 [in Ukrainian].

2. Hordiienko V. Ukrainski Sichovi Striltsi. [Ukrainian Sich Riflemen]. Lviv: «Lviv», 1990. 134 p. [in Ukrainian].

3. Horniatkevych D. Zhmut spomyniv pro Osypa Sorokhteia. [A bunch of memories of Osip Sorokhtey]. Zbruč / Krakivski visti. Lviv. URL: https://zbruc.eu/node/62915. [in Ukrainian].

4. Kuzmenko T. Mystetsko-khudozhnia tvorchist ukrainskykh sichovykh striltsiv u konteksti rozvytku natsionalnoi kultury pershoi chverti XX stolittia. [Features of forming the Ukrainian Sich Riflemen art in the context of the national culture of the first quarter of the XX century]. Questions of culturology. Kyiv, 2017. №. 32. P. 89-110. [in Ukrainian].

5. Makoida O. Osyp-Roman Sorokhtei ta striletski chasopysy. [Osyp-Roman Sorokhtey and Riflemen's Press Magazines]. Institute of Ethnology of the National Academy of Sciences of Ukraine. Lviv, 2007. № 2. P. 45-52. [in Ukrainian].

6. Rozhak-Lytvynenko K. Mystetske uhrupovannia ukrainskykh sichovykh striltsiv: khudozhnyky, tradytsii, zhanrovi ta stylovi osoblyvosti tvoriv: dys. ... spets. 17.00.05 Obrazotvorche mystetstvo. [Artistic group of Ukrainian Sich Riflemen: artists, traditions, genre and stylistic features of works: dis. ... Special. 17.00.05 Fine arts]. Lviv - 2017. 380 p. [in Ukrainian].

7. Fihol M. Vystavka tvoriv khudozhnyka-karykaturysta Osypa Yosafatovycha Sorokhteia, prysviachena 80-richchiu z dnia narodzhennia: Prospekt. [Exhibition of works by cartoonist Osip Yosafatovych Sorokhtei, dedicated to the 80th anniversary of his birth: Prospect]. Ivano-Frankivsk: Obldrukarnia, 1971. 19 p. [in Ukrainian]. 